\title{
Characterization of Protein Hydrolysates from Eel (Anguilla marmorata) and Their Application in Herbal Eel Extracts
}

\author{
I-Chun Cheng ${ }^{1}$, Jin-Xian Liao ${ }^{1}$, Jhih-Ying Ciou ${ }^{2}$, Li-Tung Huang ${ }^{3,4}$, Yu-Wei Chen ${ }^{5}$ and \\ Chih-Yao Hou $1, *$ (D) \\ 1 Department of Seafood Science, National Kaohsiung University of Science and Technology, No. 142, \\ Haijhuan Rd., Nanzih Dist., Kaohsiung City 81157, Taiwan; s0928522928@gmail.com (I-C.C.); \\ j0920181@gmail.com (J.-X.L.) \\ 2 Department of Food Science, Tunghai University, No. 1727, Section 4, Taiwan Boulevard, Xitun District, \\ Taichung City 40704, Taiwan; jyciou@thu.edu.tw \\ 3 Institute for Translational Research in Biomedicine, College of Medicine, Kaohsiung Chang Gung Memorial \\ Hospital and Chang Gung University, Kaohsiung 833, Taiwan; huangli@cgmh.org.tw \\ 4 Department of Traditional Medicine, Chang Gung University, Linkow 333, Taiwan \\ 5 Department of Medicine, Chang Gung University, No. 259, Wenhua 1st Rd., Guishan Dist., \\ Taoyuan City 33302, Taiwan; naosa720928@gmail.com \\ * Correspondence: chihyaohou@gmail.com; Tel.: +886-985300345; Fax: +886-7-3640634
}

Received: 17 December 2019; Accepted: 7 February 2020; Published: 8 February 2020

\begin{abstract}
The enzymatic hydrolysis of fish proteins is the principle method for converting under-utilized fish into valuable products for the pharmaceutical and health food industries. In this study, three commercial enzymes (alcalase, bromelain, and papain) were tested for their ability to create eel protein hydrolysates (EPHs) from whole eel (Anguilla marmorata). Freeze-dried EPHs had almost more than $80 \%$ solubility $(p<0.05)$ in solutions ranging from $\mathrm{pH} 2-10$. The amino acid profiles of the EPHs showed a high percentage of essential amino acids, including histidine, threonine, valine, isoleucine, and leucine. The emulsion activity index (EAI) of EPH resulted as follows: alcalase group $(36.8 \pm 2.00)>$ bromelain group $(21.3 \pm 1.30)>$ papain group $(16.2 \pm 1.22)$, and the emulsion stability index $(\mathrm{ESI})$ of EPH was: alcalase group $(4.00 \pm 0.34)>$ bromelain group $(2.62 \pm 0.44)>$ papain group $(1.44 \pm 0.09)$. As such, EPH has a high nutritional value and could be used as a supplement to diets lacking protein. EPH showed excellent solubility and processed interfacial properties, which are governed by its concentration. Among of them the alcalase group had the best antioxidant effect at 1,1-diphenyl-2-pyridinohydrazinyl (DPPH) radical method, determination of reducing power and ABTS test compared with other groups. EPH may be useful in developing commercial products like herbal eel extracts that are beneficial to human health.
\end{abstract}

Keywords: Anguilla marmorata; eel protein hydrolysates; functional properties; herbal eel extracts

\section{Introduction}

As the world's population continues its expansion towards nearly 10 billion people by 2050, increasing wealth in developing countries adds to the demand for protein [1], an essential component of the human diet. This is due to changing food preferences and a growing recognition of the importance of protein as a key dietary ingredient. Dietary protein supplements are becoming popular, especially for people on restricted diets, like athletes and the elderly [2]. Dairy and soy are the main sources of protein in nutritional beverages and herbal extract products, with a whey protein concentration of $80 \%$ the most widely used. However, fish is an excellent source of protein, with proven satiating effects and 
higher protein content than most terrestrial animals. The proper utilization of limited aquatic resources has been a topic of great interest for many decades. The use of proteases in fish processing leads to the hydrolysis of proteins in the source material, which can then be separated from the muscle $[3,4]$ and used in beverage or herbal products.

Anguillid eels are one of the main high value species of fish used in aquaculture, with the Japanese eel (Anguilla japonica) and European eel (Anguilla anguilla) the most popular [5,6]. World production and consumption of Anguilla sp. eels in 1987 was 100,000-110,000 tons and $\sim 70-80 \%$ of it was produced and consumed in Japan and Taiwan [7]. Eel has been an important aquatic export in these countries for nearly 30 years. In recent years, there has been a severe shortage of Anguilla japonica glass eels, as artificial propagation of freshwater eels had not yet been commercially successful. Most eel seedlings come from natural fishing, which has prompted a search for other Anguilla species, such as Anguilla marmorata. These adult eels are greyish-yellow with a white belly and brownish-black marbling on their backs that can fade over time. Mass production of Anguilla marmorata has been cultivated gradually and its breeding habits are still being explored, but little research exists on its functionality [8]. Anguilla marmorata are not only economically valuable, but are also rich in nutritional value due to their high levels of proteins, Carnosine, vitamins, and minerals $[9,10]$. However, research into Anguilla marmorata is relatively rare. Recent research into fish protein hydrolysates (FPHs) and their antioxidant activity, for instance skin gelatin hydrolysates from brownstripe red snapper or meat protein hydrolysates from yellowstripe trevally (Selaroides leptolepis) [11,12], show that hydrolysis can release functional peptides which may be used in numerous food products. R. Hartmann and H. Meisel (2007) pointed out that many peptides released in vitro or in vivo from animal or plant proteins are bioactive and have regulatory functions in humans beyond normal adequate nutrition. Different health effects have been attributed to food-derived peptides [13]. Water-holding and fat-binding capacities are functional properties that are closely related to texture based on the interactions between water, oil, and other components [14]. Protein hydrolysates rich in bioactive compounds represent promising ingredients for food and industrial applications. Some recent studies have gone beyond producing and characterizing EPH and have tested their ability to fortify foods $[15,16]$. Because the protein hydrolysates characterization and process application properties research of Anguilla marmorata is relatively few, and protein hydrolysates are often used in nutritional supplements. Therefore, the objectives of this study are to compare the use of three commercial enzymes (alcalase, bromelain and papain) in the production of eel protein hydrolysates (EPHs) and to characterize these EPHs, compare their chemical, functional properties, and sensory properties, and application to herbal eel extracts.

\section{Results and Discussion}

\subsection{Enzyme Activity and Degree of Hydrolysis}

Before hydrolysis, an enzyme activity assay was performed to estimate the quality of the respective enzyme. Proteolytic activity for each enzyme was: alcalase $2.4 \mathrm{~L}$ at $2500 \mathrm{U} / \mathrm{mg}$, papain at 10,000 U/mg, and bromelain at $1250 \mathrm{U} / \mathrm{mg}$. Alcalase is produced from microbes while the other two enzymes are produced from plants. Of the three, bromelain had the lowest activity level. Degree of hydrolysis (DH) is defined as the percentage of peptide bonds cleaved and it is the standard parameter commonly used to monitor and compare the level of protein proteolysis, which also affects protein solubility, emulsification, and foaming. Protein hydrolysates with high solubility can be easily mixed into liquid and have excellent wettability. Different $\mathrm{DH}$ values affect the structure and amino acid composition. Figure 1a shows the $\mathrm{DH}$ for alcalase, bromelain, and papain at optimal $\mathrm{pH}$ and temperature $(\mathrm{pH} 7.5$ and $55^{\circ} \mathrm{C}, \mathrm{pH} 4.5$ and $45^{\circ} \mathrm{C}$, and $\mathrm{pH} 6.0$ and at $50{ }^{\circ} \mathrm{C}$, respectively) for different reaction times (from $1 \mathrm{~h}$ to $16 \mathrm{~h}$ ). Figure $1 \mathrm{~b}$ shows $\mathrm{DH}$ depending on the amount of enzyme added (from 0.1 to $2.0 \mathrm{~g} / \mathrm{g}$ ). In Figure 1a, there are significant differences in DH between the enzymes, as alcalase shows greater hydrolytic ability than bromelain or papain. Similar results are seen in Figure 1b, with alcalase still showing the greatest degree of hydrolysis. The functionality of protein hydrolysates is a major 
factor in their success as functional supplements in food. The physicochemical properties of protein hydrolysates depend on the protein substrate, the specificity of the enzyme used for proteolysis, and the hydrolysis conditions [14].
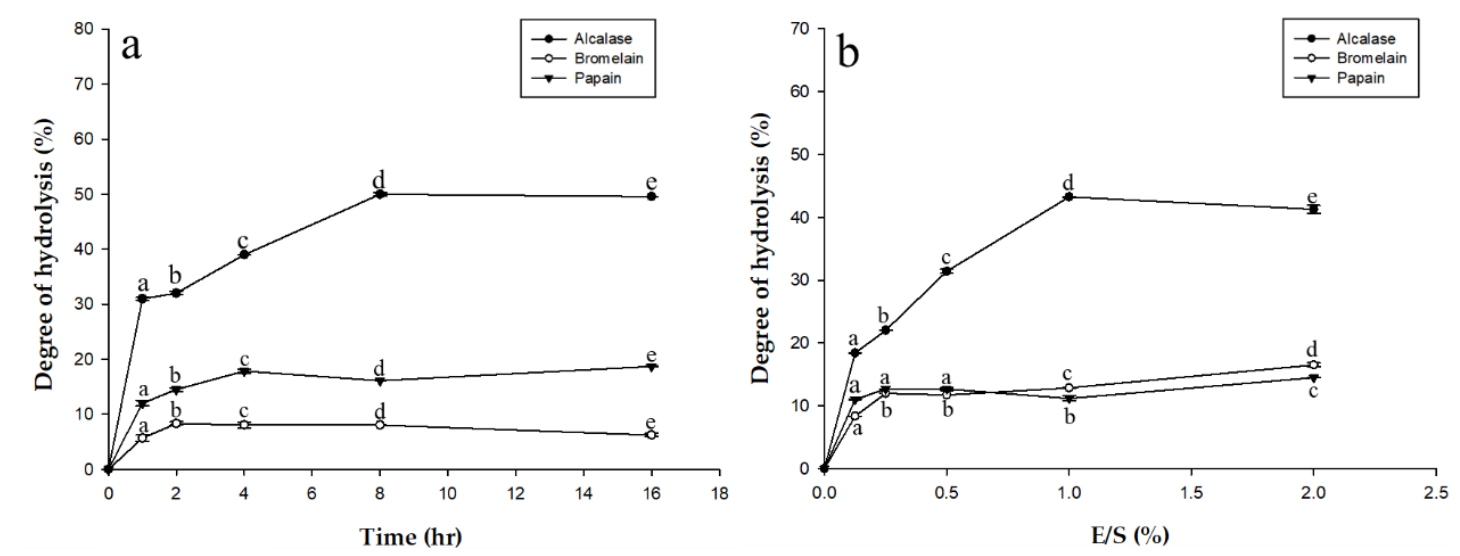

Figure 1. (a) Degree of hydrolysis of eel (Anguilla marmorata) at different times with three different commercial proteases (alcalase, bromelain, and papain) at optimal $\mathrm{pH}$ and temperature; (b) Degree of hydrolysis of eel (Anguilla marmorata) with different amounts of commercial proteases (alcalase, bromelain, and papain) at optimal $\mathrm{pH}$ and temperature. Means in the same form with various characters have significant differences $(p<0.05)$. Data are expressed as mean $\pm \mathrm{SD}$, from experiments performed in triplicate.

\subsection{Molecular Mass Distribution Profile}

Prior to enzymatic hydrolysis, the peptide molecular mass distribution of eel (Anguilla marmorata) was analyzed via high performance liquid chromatography (HPLC). All EPHs were reduced to smaller peptides with molecular mass between 1056.55 Da and 1554.53 Da (Table 1). Small molecule proteins and peptides are easier for the human body to digest and absorb which mainly include dipeptide or tripeptide [17].

Table 1. Average molecular mass of peptides in eel (Anguilla marmorata) following hydrolysis with alcalase, bromelain, and papain.

\begin{tabular}{lll}
\hline & Enzyme & Molecular mass (Da) \\
\hline & Alcalase & $1056.55 \pm 2.60^{\mathrm{a}}$ \\
$\mathrm{EPH}^{*}$ & Bromelain & $1482.24 \pm 3.36^{\mathrm{b}}$ \\
& Papain & $1554.53 \pm 19.22^{\mathrm{c}}$ \\
\hline
\end{tabular}

* Prior to enzymatic hydrolysis, eel (Anguilla marmorata) were analyzed by HPLC. ${ }^{\text {a-c }}$ Different letters in the same column denote significant differences between hydrolysates $(p<0.05)$.

\subsection{Amino Acid Composition}

Amino acid levels in the hydrolyzed EPHs were higher than in unhydrolyzed eels. Among the 20 types of standard amino acids, there are 9 essential amino acids (EAAs) that adults cannot produce and must obtain from their diet; arginine (Arg), in particular, is essential for babies. Among the EPHs, the levels of histidine (His), threonine (Thr), valine (Val), isoleucine (Ile), and leucine (Leu) were higher with alcalase than for bromelain or papain (Table 2). In fact, the alcalase EPH provided the equivalent of the World Health Organization's recommended daily intake of EAAs needed to meet the protein requirement for adults. Protein hydrolysates are mainly used in health products and energy drinks, but hydrolysis results in protein structural changes, causing bitterness. Since bitterness was produced by proline (Pro), Leu, Val, and phenylalanine (Phe), an herbal eel extract recipe was used to remove 
the unpleasant taste. The amino acid composition of the hydrolyzed eel protein solution could help supply adults with EAAs and be used to develop nutritional supplements in the future.

Table 2. Total amino acids of the three EPHs ( $\mathrm{A}=$ alcalase, $\mathrm{B}=$ bromelain, $\mathrm{P}=$ papain $)$ and recommended amino acid requirements of adults (WHO, 2002). Branched chain amino acids are highlighted in bold font. $\mathrm{WHO}=$ World Health Organization.

\begin{tabular}{cccccc}
\hline Amino Acid & Eel & A & B & P & WHO \\
\hline His * & 0.81 & 1.01 & 0.76 & 0.95 & 1.50 \\
Thr * $^{*}$ & 0.63 & 2.98 & 2.75 & 0.71 & 2.30 \\
Val $^{*}$ & 0.31 & 1.66 & 3.07 & 2.23 & 3.90 \\
Leu $^{*}$ & 1.87 & 1.93 & 1.27 & 0.15 & 3.00 \\
Asp & 1.74 & 2.85 & 1.48 & 6.77 & - \\
Glu & 4.51 & 5.14 & 5.33 & 6.95 & - \\
Ser & 7.18 & 7.10 & 6.96 & 0.92 & - \\
Gly & 0.80 & 1.48 & 2.31 & 3.09 & - \\
Ala & 0.30 & 6.38 & 5.58 & 6.37 & - \\
Pro & 5.83 & 5.03 & 5.02 & 1.02 & - \\
Arg & 1.06 & 1.37 & 0.70 & 0.55 & - \\
Phe * & 0.41 & 2.04 & 1.95 & 0.98 & \\
\hline
\end{tabular}

* required for adults. Results are expressed as the mean \pm SD from triplicate determinations. Values in the same column with different superscript letters are significantly different $(p<0.05)$.

\subsection{Functional Properties of EPHs}

The functional properties of the hydrolyzed protein solution are affected by amino acid composition and the molecular weight of the peptides. The solubility, emulsifying properties, stability, turbidity, color, oil binding capacity, and flavor are important in food processing. Functional properties can also affect the sensory evaluation, especially for chewy and smooth textures.

\subsubsection{Emulsifying Properties}

EAI is a function of oil volume fraction, protein concentration, and the type of equipment used to produce the emulsion [14] EAI $\left(\mathrm{m}^{2} \mathrm{~g}^{-1}\right)$ and ESI ( $\left.\mathrm{min}\right)$ of EPHs at different concentrations $(0.5 \%, 1 \%$, and $2 \% w / v)$ are shown in Table 3. All EPHs had reduced EAI as concentration increased. The most significant difference among the EPHs was at $0.5 \%(w / v)$ concentration, with Alcalsae having the highest EAI $\left(36.8 \pm 2.00 \mathrm{~m}^{2} \mathrm{~g}^{-1}\right)$ and papain having the lowest $\left(16.2 \pm 1.22 \mathrm{~m}^{2} \mathrm{~g}^{-1}\right)$. ESI was also significantly impacted by concentration. Similar to EAI, differences in ESI were largest at a concentration of $0.5 \%$ $(w / v)$. Alcalase had the highest ESI $(4.00 \pm 0.34 \mathrm{~min})$ at a concentration of $2 \%(w / v)$. Emulsification occurs during homogenization when proteins are absorbed at the surface of the oil droplets as they form, creating a membrane which prevents them from consolidating [18].

Table 3. Emulsifying activity index (EAI, $\mathrm{m}^{2} \mathrm{~g}^{-1}$ ) and emulsion stability index (ESI, min) at different EPH concentrations $(0.5 \%, 1 \%$, and $2 \% w / v)$ and oil binding capacities (OBC, g/g).

\begin{tabular}{|c|c|c|c|c|c|c|c|}
\hline \multirow{2}{*}{$\begin{array}{c}\text { EPH conc. } \\
\text { Alcalase }\end{array}$} & \multicolumn{3}{|c|}{$\left(E A I m^{2} g^{-1}\right)$} & \multicolumn{3}{|c|}{ ESI (min) } & $\begin{array}{c}\text { OBC (g/g) } \\
-\end{array}$ \\
\hline & $36.8 \pm 2.00^{a}$ & $19.7 \pm 1.00^{\mathrm{a}}$ & $11.3 \pm 0.28^{a}$ & $1.11 \pm 0.31^{\mathrm{a}}$ & $2.70 \pm 0.20^{a}$ & $4.00 \pm 0.34^{a}$ & $1.58 \pm 0.07^{a}$ \\
\hline Papain & $16.2 \pm 1.22^{\mathrm{c}}$ & $8.63 \pm 0.58^{c}$ & $3.25 \pm 0.10^{c}$ & $0.81 \pm 0.96^{c}$ & $1.37 \pm 0.75^{c}$ & $1.44 \pm 0.09^{c}$ & $1.12 \pm 0.01^{b}$ \\
\hline
\end{tabular}

Values are given as mean $\pm \mathrm{SD}$ from triplicate determinations $(n=3) .{ }^{\mathrm{a}-\mathrm{c}}$ Different letters in the same column denote significant differences between hydrolysates $(p<0.05)$. 


\subsubsection{Oil Binding Capacity (OBC)}

Oil binding capacity was determined by physical methods, the density of oil in the bulk, and use the ratio of the mass of bound liquid oil to the solid fat content. In this study, alcalase has the highest OBC value of the three EPHs (Table 3). The oil binding capacity of a protein affects its functional properties and the taste of the end product. Water-holding and fat-binding capacities are functional properties that are closely related to texture, due to the interactions between water, oil, and other components.

\subsection{Antioxidant Properties of EPHs}

Antioxidants are very important in food preservation, and also play an important role in improving immunity and delaying human aging. In Figure 2a, DPPH free radical scavenging activity was compared for the three enzymes (alcalase, bromelain, and papain) at different times. Bromelain had significantly higher scavenging activity than the other enzymes. Figure $2 b$ shows the DPPH free radical scavenging activity of EPHs at different concentration. The results for alcalase are significantly higher. Alcalase addition ratios of 1.0 and 2.0 resulted in significantly higher scavenging ability. Figure $2 c$, $d$ used the reducing power assay to compare antioxidant activity at different times and with different amounts of the enzymes. Of the three, the alcalase hydrolysate had the highest reducing power. Figure 2e,f compare the impact hydrolysis time and the amount of enzyme have on ABTS total antioxidant capacity. Of the three, bromelain has a significantly higher ABTS total antioxidant capacity. Antioxidant tests were performed for three different mechanisms. As such, the antioxidant capacities of the EPHs are clearly different, since they were hydrolyzed by different enzymes, with different hydrolysis times, and with differing amounts of enzymes. However, based on all three assays, the alcalase hydrolysate appears to have the greatest total antioxidant capacity.
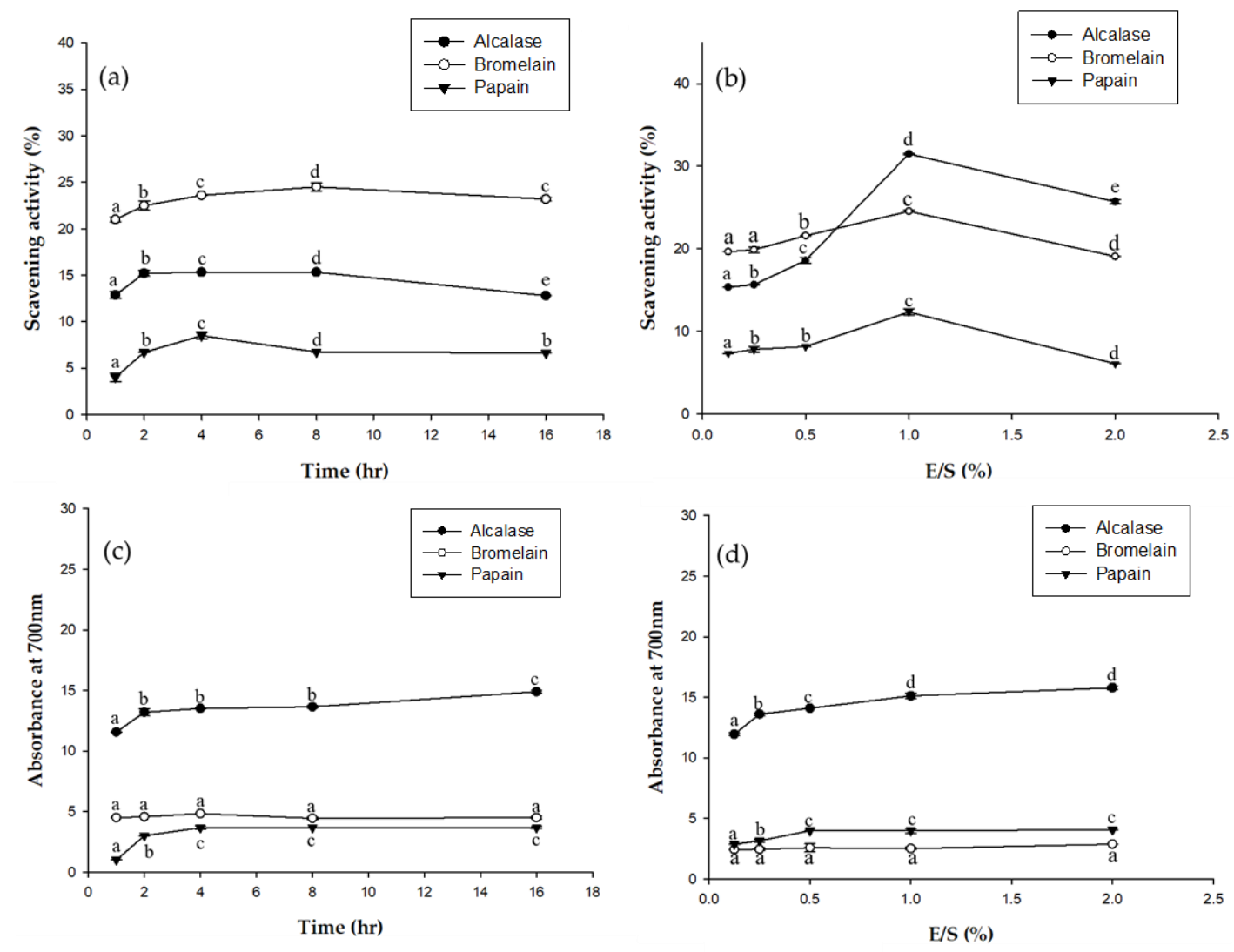

Figure 2. Cont. 

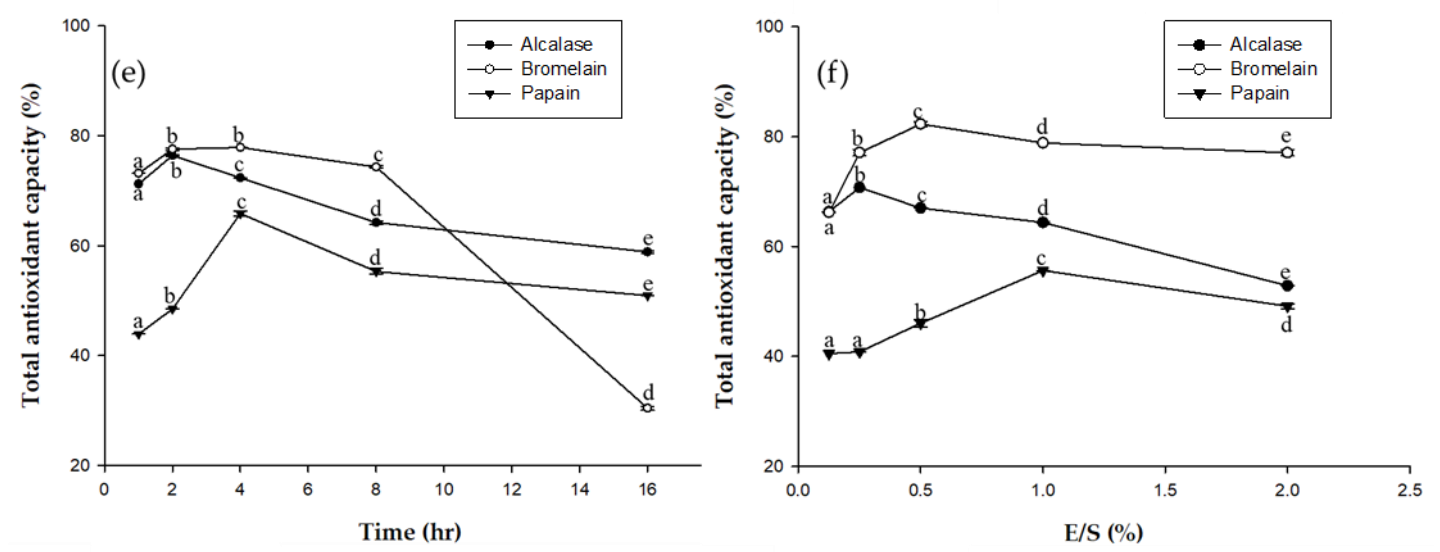

Figure 2. Antioxidant effect of the three EPHs (alcalase, bromelain, and papain) using three antioxidant assays: (a) Antioxidant effect at different times based on DPPH free radical scavenging assay; (b) Antioxidant effect at different enzyme concentrations based on DPPH free radical scavenging assay; (c) Antioxidant effect at different times based on reducing power assay; (d) Antioxidant effect at different enzyme concentrations based on reducing power assay; (e) Antioxidant effect at different time based on ABTS total antioxidant capacity; (f) Antioxidant effect at different enzyme concentrations based on ABTS total antioxidant capacity. Means in the same form with various characters denote significant differences $(p<0.05)$. Data are expressed as mean \pm SD from triplicate determinations.

\subsection{Nitrogen Solubility of EPH and Herbal Eel Extracts}

Solubility is often considered the most important physicochemical property in protein hydrolysates, especially when considered in terms of fortifying herbal extracts. Many other functional properties, such as emulsification and foaming, are affected by solubility. Figure 3a shows the nitrogen solubility profile as a function of $\mathrm{pH}$ for EPHs produced from different enzymes. All three EPHs had high solubility (more than $80 \%$ ) in different $\mathrm{pH}$ conditions and $85 \%$ solubility in alkaline conditions. Among them, EPH produced from alcalase performed the best. At low $\mathrm{pH}$, the charges on the weakly acidic and basic side-chains of the amino acids become less soluble, and resulted in precipitation [18]. The reduced solubility of the alcalase hydrolysate may be due to the greater proportion of small molecule amino acids due to their hydrophilic relationship to the water molecules prior to nitrogen solubility analysis. As shown in Figure $3 \mathrm{~b}$, the $\mathrm{pH}$ of the herbal eel extract was $7.0 \pm 1$, and it showed good solubility at higher $\mathrm{pH}$. The beverage matrix will contain other compounds that promote or hinder solubility. Higher solubility gives food and beverage products an appealing appearance and a smooth mouthfeel.
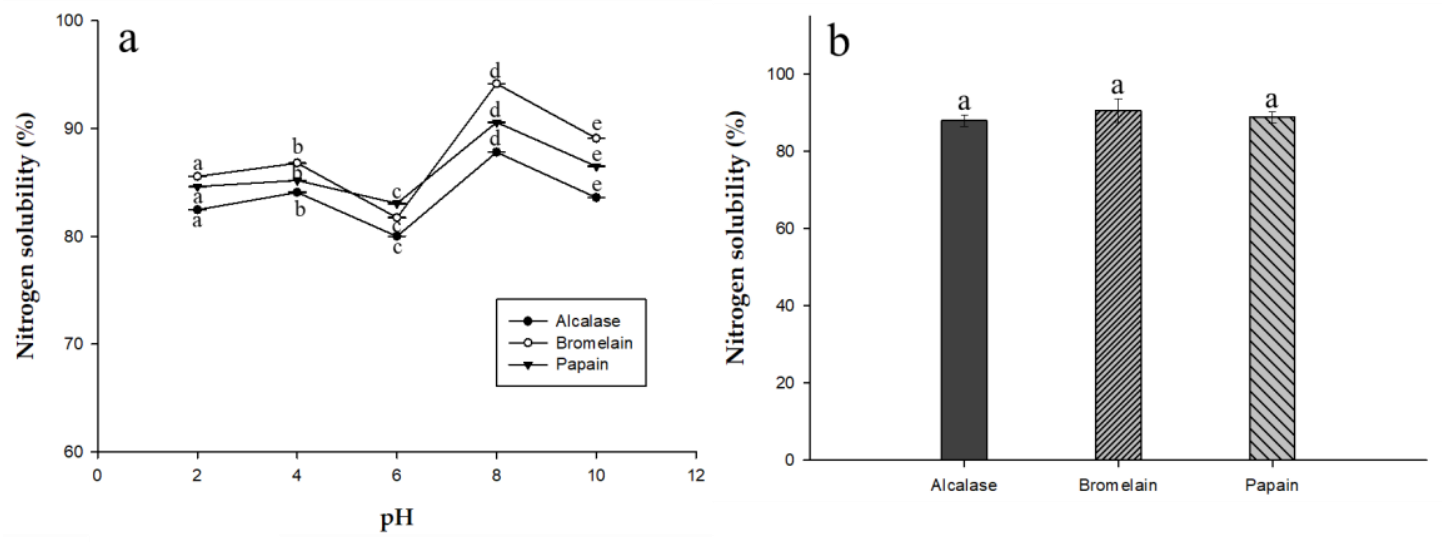

Figure 3. Nitrogen solubility (\%) of the three EPHs in (a) water at different pH levels $(2,4,6$, 8, and 10) and (b) herbal eel extracts. Means in the same form with various characters have significant differences $(p<0.05)$. Data are expressed as mean \pm SD from triplicate determinations. 


\subsection{Color of EPH and Herbal Eel Extracts}

In the food industry, food color is the deciding factor in consumers' overall acceptance of a product. The color of eel protein hydrolysates is based on the ingredients, enzymes, and hydrolysis conditions. At a concentration of $15 \%(w / v)$, there were significant differences between the EPHs. As summarized in Table 4, $\mathrm{L}^{*}$ represents brightness, while $\mathrm{a}^{*}$ and $\mathrm{b}^{*}$ represent the color space. Both the EPHs and the herbal eel extract were brownish-yellow in color. Specifically, all three EPHs were yellowish in color, although alcalase $(3.96 \pm 0.04)$ was darker than both bromelain $(6.37 \pm 0.43)$ and papain $(8.10 \pm 0.18)$. Based on $a^{*}$ value, alcalase $(0.42 \pm 0.03)$ was preferable to bromelain $(0.78 \pm 0.02)$ and papain $(0.28 \pm 0.01)$. The same trend was seen with the $b^{*}$ value, with alcalase $(0.74 \pm 0.07)$ again preferable to both bromelain $(2.39 \pm 0.02)$ and papain $(5.75 \pm 0.10)$. The color differences were mainly due to the ingredient sources and enzymes. Alcalase had the lowest brightness and therefore showed the darkest color following hydrolysis.

Table 4. Color analysis of the three EPHs (alcalase, bromelain, and papain) at concentration of $15 \%$ $(1.5 \mathrm{~g} / 10 \mathrm{~mL})$.

\begin{tabular}{ccccc}
\hline & & Alcalase & Bromelain & Papain \\
\hline EPH & $L^{*}$ & $3.96 \pm 0.04^{\mathrm{c}}$ & $6.37 \pm 0.43^{\mathrm{b}}$ & $8.10 \pm 0.18^{\mathrm{a}}$ \\
& $a^{*}$ & $0.42 \pm 0.03^{\mathrm{b}}$ & $0.78 \pm 0.02^{\mathrm{a}}$ & $0.28 \pm 0.01^{\mathrm{c}}$ \\
& $b^{*}$ & $0.74 \pm 0.07^{\mathrm{c}}$ & $2.39 \pm 0.02^{\mathrm{b}}$ & $5.75 \pm 0.10^{\mathrm{a}}$ \\
\hline Herbal extract & $L^{*}$ & $2.17 \pm 0.00^{\mathrm{c}}$ & $2.59 \pm 0.04^{\mathrm{b}}$ & $4.52 \pm 0.07^{\mathrm{a}}$ \\
with 15\% EPH & $a^{*}$ & $0.98 \pm 0.00^{\mathrm{a}}$ & $0.62 \pm 0.00^{\mathrm{c}}$ & $0.78 \pm 0.11^{\mathrm{b}}$ \\
$(1.5 \mathrm{~g} / 10 \mathrm{~mL})$ & $b^{*}$ & $2.68 \pm 0.00^{\mathrm{c}}$ & $3.75 \pm 0.06^{\mathrm{b}}$ & $5.84 \pm 0.05^{\mathrm{a}}$ \\
\hline
\end{tabular}

Values are given as mean $\pm \mathrm{SD}$ from triplicate determinations $(n=3)$. ${ }^{\mathrm{a}-\mathrm{c}}$ Different letters in the same column denote significant differences between hydrolysates $(p<0.05)$.

\section{Materials and Methods}

\subsection{Materials}

2,2-diphenyl-1-picrylhydrazyl, phthaldialdehyde, and trifluoroacetic acid were purchased from Alfa Aesar (Haverhill, MA, USA). Glycerol and ascorbic acid were purchased from R\&D Systems (Minneapolis, MN, USA). Glacial acetic acid was purchased from ThermoFisher Scientific (Waltham, MA, USA). Anhydrous iron (III) chloride, citric acid monohydrate, and sodium tetraborate decahydrate were purchased from Showa Chemical Industry Company (Tokyo, Japan). Methanol, hydrochloric acid, sodium bicarbonate, and anhydrous sodium acetate were purchased from Aencore Chemical Co. (Melbourne, VIC, Australia). Disodium (hydrogen) phosphate was purchased from J.T. Baker (Phillipsburg, NJ, USA). Hydrogen peroxide was purchased from SHOWA (Japan). Alcalase ${ }^{2} 2.5 \mathrm{~L}$ was purchased from Strem Chemicals (Newburyport, MA, USA, CAS number 9014-01-1), and papain (CAS number 9001-73-4) and bromelain (CAS number 9001-00-7) were purchased from ChappionBio (Taiwan). Olive oil was purchased from Carrefour (Taiwan).

\subsection{Methods}

\subsubsection{Anguilla Marmorata Raw Material Preparation}

Anguilla marmorata were provided by the Honya eel farm (Dongshi Township, Cjiayi County, Taiwan). The heads of the eels were excised, and the skin and bones were removed. The remaining fish was sterilized at $121^{\circ} \mathrm{C}$ for $30 \mathrm{~min}$ before storage at $-20^{\circ} \mathrm{C}$ for subsequent experiments and analysis.

\subsubsection{Anguilla Marmorata Meat Hydrolysate Preparation}

$1 \mathrm{~g}$ eel meat was added to $0.1 \mathrm{M}$ phosphate-citrate buffer solution ( $\mathrm{pH} 7.5)$ at a 1:50 ratio then homogenized, before the addition of different concentrations of the three enzymes, as shown in Table 5 . 
The enzyme was inactivated by heating the solution to $95^{\circ} \mathrm{C}$ for $20 \mathrm{~min}$ before it was freeze-dried to obtain EPH. The sample was then stored at $-20^{\circ} \mathrm{C}$ until further analysis. The scheme of the hydrolysis process of Anguilla marmorata is shown in Figure 4.

Table 5. Parameters used to obtain the optimal hydrolysis conditions for eel, using three different enzymes.

\begin{tabular}{lccccc}
\hline \multirow{2}{*}{ Factors } & \multirow{2}{*}{ Unit } & \multirow{2}{*}{ Symbol } & \multicolumn{3}{c}{ Enzyme } \\
\cline { 4 - 6 } & & & Alcalase & Bromelain & Papain \\
\hline Temperature & ${ }^{\circ} \mathrm{C}$ & $\mathrm{T}$ & 55 & 55 & 45 \\
Time & $\mathrm{h}$ & $\mathrm{t}$ & & $1.0,2.0,4.0,8.0,16.0$ & \\
Enzyme & $\%$ & $\mathrm{E} / \mathrm{S}$ & & $0.125,0.25,0.5,1.0,2.0$ & \\
concentration & $\%$ & & & & \\
\hline
\end{tabular}

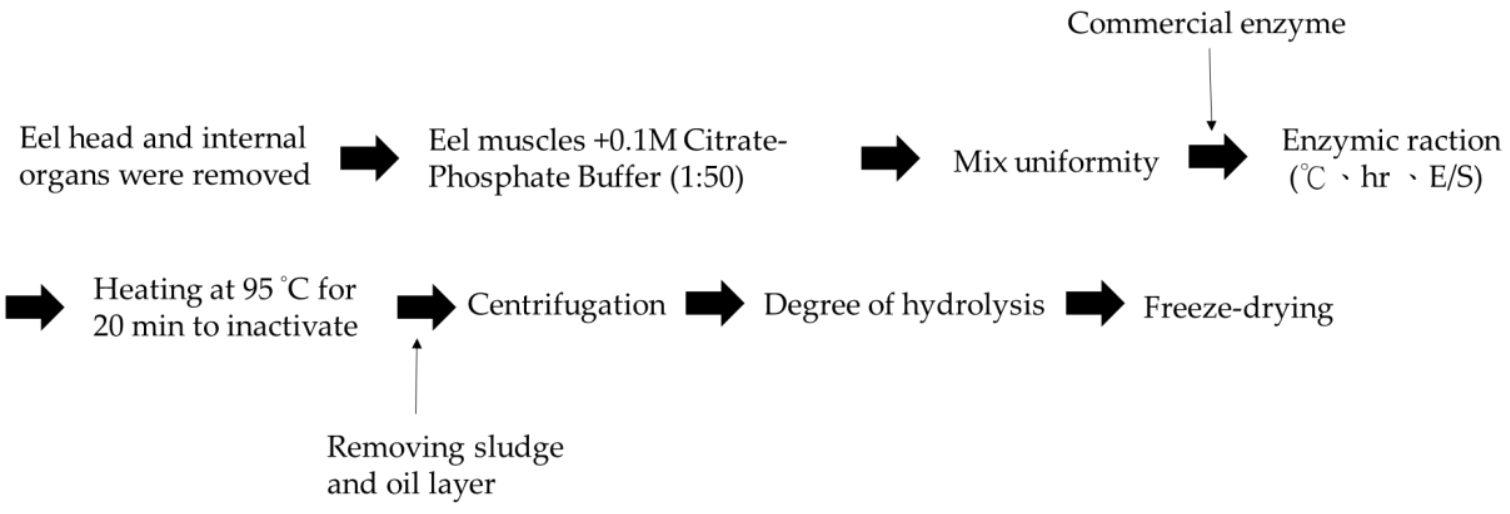

Figure 4. Scheme of the hydrolysis process of Anguilla marmorata.

\subsubsection{Herbal Eel Extracts}

The recipe of herbal eel extracts is to add $23 \mathrm{~g}$ of wolfberry, $20 \mathrm{~g}$ of red dates, $8 \mathrm{~g}$ of Astragalus propinquus, $8 \mathrm{~g}$ Angelica sinensis, $6 \mathrm{~g}$ Cinnamomum cassia, $6 \mathrm{~g}$ Licorice to the medicine bag, and put into the $1000 \mathrm{~mL}$ water contains $49 \mathrm{~g}$ sugar and $6 \mathrm{~g}$ salt for boil $30 \mathrm{~min}$ together. After cooling down remove the medicine bag and mix with $500 \mathrm{~mL}$ of $15 \% \mathrm{EPH}$ as herbal eel extract for assay.

\subsubsection{Determination of Degree of Hydrolysis (DH)}

The degree of hydrolysis (DH), defined as the percentage ratio of the number of peptide bonds cleaved to the total number of peptide bonds available in the substrate, was monitored throughout the reaction. $100 \mathrm{ppm}$ serine (Seine) standard and a sample containing $0.08 \%$ protein content were added to $150 \mu \mathrm{L}$ OPA colorant $(1 \mathrm{~mL} 4 \%$ o-phthalaldehyde in ethanol added to $40 \mathrm{~mL} 1250 \mathrm{ppm}$ sodium dodecyl sulfate in $0.125 \mathrm{M}$ sodium tetraborate buffer solution, further dissolved in $44 \mathrm{mg}$ of dithiothreitol to $50 \mathrm{~mL}$ ). The reaction was allowed to stand for $2 \mathrm{~min}$, before absorbance was measured by an ELISA reader at $340 \mathrm{~nm}$ [19].

$\mathrm{DH}(\%)=[(\mathrm{OD}($ Sample $)-\mathrm{OD}($ Blank $)) /(\mathrm{OD}($ Standard $)-\mathrm{OD}($ Blank $)) \times 0.9516$ meqv $/ \mathrm{L} \times 0.1 /(\mathrm{X} \times \mathrm{P})-\beta] / \alpha / \mathrm{h}_{\text {tot }} \times 100 \%$

where OD $($ Standard $)=$ standard absorbance, OD (Sample $)=$ sample absorbance, $\mathrm{OD}($ Blank $)=$ blank absorbance, $\mathrm{X}=\mathrm{g}$ sample, and $\mathrm{P}=$ protein $\%$ in sample.

The values of the constants $\alpha, \beta$, and $h_{\text {tot }}$ (total number of peptide bonds per protein equivalent, which is dependent on the amino acid composition of the raw material) for fish protein are estimated to be $1.00,0.40$, and 8.6 , respectively. 


\subsubsection{Molecular Mass Identification}

Each EPH was filtered and its molecular mass determined by HPLC (Hitachi, Chromaster, Japan) and BioSep-SEC-S $2000(600 \times 7.8 \mathrm{~mm})$. The mobile phase used was $45 \%(v / v)$ acetonitrile with $1 \%$ trifluoracetic acid buffer at a rate of $1 \mathrm{~mL} / \mathrm{min}$ by gradient. $25 \mu \mathrm{L}$ of the sample was injected and determined at $214 \mathrm{~nm}$. The molecular mass was analyzed by the standard curve with standard proteins maltose $(360 \mathrm{Da})$, apoinin $(6500 \mathrm{Da})$, ribonuclease $(13,700 \mathrm{Da})$, and carbonic anhydrase $(29,000 \mathrm{Da})$.

\subsubsection{Analysis of Amino Acid Composition}

The sample or standard was dissolved in $0.1 \mathrm{~N} \mathrm{HCl}$, before $50 \mu \mathrm{L}$ was added to $250 \mu \mathrm{L}$ of $50 \mathrm{mM} \mathrm{NaHCO} 3(\mathrm{pH} 8.1)$ and $200 \mu \mathrm{L}$ of DABS-Cl solution $(1.3 \mathrm{mg} / \mathrm{mL})$ was dissolved in acetonitrile. The reaction was shaken for $5 \mathrm{~min}$, then placed in a water bath at $70{ }^{\circ} \mathrm{C}$ for $12 \mathrm{~min}$. After cooling to room temperature (about $5 \mathrm{~min}$ ), $300 \mu \mathrm{L}$ of $70 \%$ ethanol was added to stop the reaction and the sample was filtered through a $0.45 \mu \mathrm{m}$ PVDF filter, using methods previously described [20].

Mobile phase:

(1) Solution A: $25 \mathrm{mM}$ sodium acetate solution ( $\mathrm{pH}$ 6.5) containing 4\% dimethylformamide

(2) Solution B: acetonitrile

Flow rate setting: $1 \mathrm{~mL} / \mathrm{min}$

Gradient setting: initial concentration (solution A: solution B = 85: 15)

$0 \sim 5$ min (solution A: solution $B=78.7: 21.3$ )

5 60 min (solution A: solution $B=70: 30$ )

60 70 min (solution A: solution B = 30: 70)

70 75 min (solution A: solution B $=30: 70$ )

75 76 min (solution A: solution B $=30: 70$ )

76 80 min (solution B: solution $C=15: 85$ )

80 86 min (solution A: solution B $=85: 15$ )

86 90 min (solution A: solution B $=85: 15$ )

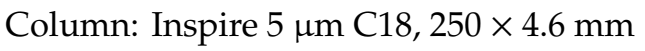

Detection wavelength: $436 \mathrm{~nm}$

\subsubsection{Functional Properties}

Nitrogen Solubility of EPH and Herbal Eel Extracts

Nitrogen solubility was initially determined in distilled water over a range of $\mathrm{pH}$ values $(2,4$, 6, 8, and 10), as described elsewhere [14]. $200 \mathrm{mg}$ of EPH was added to $30 \mathrm{~mL}$ distilled water and mixed, then centrifuged at room temperature $(5000 \mathrm{rpm}, 20 \mathrm{~min}$ ) and filtered (ADVANTEC paper no. 1). The nitrogen content of the resulting supernatant was determined using the Kjeldahl method and the nitrogen solubility was calculated as follows:

$$
\text { Nitrogen solubility }(\%)=\frac{N_{1}}{N_{0}} \times 100
$$

where $N_{1}=$ supernatant nitrogen concentration and $N_{0}=$ sample nitrogen concentration. Solubility analysis was carried out in triplicate. Subsequently, nitrogen solubility of the herbal eel extracts was determined following the method above.

\section{Emulsifying Properties}

The emulsion activity index (EAI) and emulsion stability index (ESI) of each EPH was determined with some modifications [14]. EPHs were reconstituted in distilled water $(15 \mathrm{~mL})$ at concentrations of $0.5 \%, 1 \%$, and $2 \%(w / v)$. Olive oil $(5 \mathrm{~mL})$ was homogenized with the EPH solution for $1 \mathrm{~min}$ at room temperature. $50 \mu \mathrm{L}$ aliquots of the emulsion were taken from the bottom of the conical flask directly 
after homogenization and again 10 min later, then diluted 100 -fold in $0.1 \%(w / v)$ SDS solution. The new solution was mixed for $10 \mathrm{~s}$ and the absorbance measured at $500 \mathrm{~nm}$

$$
\begin{gathered}
\text { ESI } m^{2} g^{-1}=\frac{2 \times 2.303 \times A_{0}}{0.25 \times \text { Protein weight }(g)} \\
\text { ESI }=\frac{\Delta A}{A_{0}} \times t
\end{gathered}
$$

where $\mathrm{A}=$ absorbance, $\Delta \mathrm{A}=(\mathrm{A} 0-\mathrm{A} 10)$ and $\mathrm{t}=10 \min \left(\mathrm{A}_{0}=\right.$ Absorbance at $0 \min , \mathrm{A}_{10}=$ absorbance at $10 \mathrm{~min})$.

\subsubsection{Antioxidant Capacity Analysis}

Analysis of Reducing Power

Ascorbic acid was used as a standard. $200 \mu \mathrm{L}$ of the standard and sample were mixed with $200 \mu \mathrm{L}$ of $200 \mathrm{mM}$ phosphate buffer solution ( $\mathrm{pH}$ 6.6) and $200 \mu \mathrm{L}$ of $1 \%$ potassium ferricyanide, then allowed to react in a $50{ }^{\circ} \mathrm{C}$ water bath for $20 \mathrm{~min} .200 \mu \mathrm{L}$ of $10 \%$ trichloroacetic acid solution was then added, and $200 \mu \mathrm{L}$ of the supernatant was combined with $200 \mu \mathrm{L}$ of distilled water and $40 \mu \mathrm{L}$ of a $0.1 \%$ ferric chloride solution dissolved in $10 \% \mathrm{HCl}$. After standing for $10 \mathrm{~min}$, the absorbance of the solution was measured using an ELISA plate reader at a wavelength of $700 \mathrm{~nm}$ [21].

Analysis of DPPH Free Radical Scavenging Ability

Using ascorbic acid as a standard, $160 \mu \mathrm{L}$ of the standard and sample were added to $40 \mu \mathrm{L}$ of $1 \mathrm{mM}$ DPPH dissolved in methanol, then protected from the light for $30 \mathrm{~min}$. The absorbance was measured using a reader at a wavelength of $517 \mathrm{~nm}$ [22].

\section{ABTS Radical-Scavenging Activity Assay}

The stock solution of 2,2' -azino-bis-(3-ethylbenzothiazoline-6-sulfonic acid (ABTS) radical was produced by reacting $7 \mathrm{mM}$ ABTS with $2.45 \mathrm{mM} \mathrm{K}_{2} \mathrm{~S}_{2} \mathrm{O}_{8}$ (final concentration) and allowing the mixture to stand in dark incubation for $12 \mathrm{~h}$ at room temperature condition. The ABTS radical working solution was diluted with phosphate buffered saline (PBS) (pH7.4) at $730 \mathrm{~nm}$ to absorbance of $0.70( \pm 0.02) .1 \mathrm{~mL}$ of diluted solution is added with $10 \mu \mathrm{L}$ of different sample and reacted for a minute, then tested under $730 \mathrm{~nm}[23]$.

\subsubsection{Color of EPH and Herbal Eel Extracts}

Aliquots of EPH were diluted to $15 \%(w / v)$ and the herbal eel extracts to measured three times by a color difference meter (Nippon Denshoku Industries Co., Ltd., SA2000, Japan). L* denoted brightness, $a^{*}$ indicated red green and $b^{*}$ indicated yellow-blue values [24].

\subsubsection{Statistical Analysis}

Data are expressed as the mean \pm standard deviation of three independent replicates. Statistical analysis was performed using the software SPSS statistics v24. All data were analyzed using one-way analysis of variance (ANOVA). Post hoc analysis of group differences was performed using Duncan's new multiple range tests. The criterion for significance was set at $p<0.05$.

\section{Conclusions}

This study has shown that eel (Anguilla marmorata) are a good source of highly nutritious protein. Through hydrolysis, three commercial enzymes (alcalase, bromelain, and papain) produced low molecular mass peptides that are easy to digest. Among the three, the EAA content in the alcalase-hydrolyzed EPH was the most similar to the daily dose recommended by WHO. EAI was 
highest with the alcalase EPH $(36.8 \pm 2.00)$, while the bromelain and papain EPHs had EAI values of $21.3 \pm 1.30$ and $16.2 \pm 1.22$, respectively. Alcalase $\mathrm{EPH}$ also had a higher solubility $(>80 \%)$ in a $\mathrm{pH}$ range of 2 to 10, as well as demonstrating the greatest antioxidant capacity. Finally, the alcalase-hydrolyzed $\mathrm{EPH}$ had a brighter color, good emulsifying properties, and showed good solubility, making it useful in food processing. In future studies of our research will investigate the fractionation, purification, structure identification of EPH then evaluate human nutrition efficacy by animal model assessment potential application of EPH.

Author Contributions: Conceptualization, L.-T.H., Y.-W.C., and C.-Y.H.; Data curation, I-C.C., J.-X.L., Y.-W.C., and J.-Y.C.; Formal analysis, I-C.C., J.-X.L., and Y.-W.C.; Funding acquisition, Y.-W.C., J.-Y.C., and C.-Y.H.; Investigation, I-C.C. and J.-X.L.; Methodology, I-C.C., J.-X.L., and C.-Y.H.; Project administration, C.-Y.H.; Resources, J.-Y.C.; Software, I-C.C., Y.-W.C., and C.-Y.H.; Supervision, L.-T.H. and J.-Y.C.; Validation, J.-X.L. and L.-T.H.; Visualization, J.-X.L. and L.-T.H.; Writing—original draft, L.-T.H. and C.-Y.H.; Writing—review and editing, J.-Y.C. and C.-Y.H. All authors have read and agreed to the published version of the manuscript.

Funding: This research was funded by the National Kaohsiung University of Science and Technology, grant number NKUST-108D04 and The APC was funded by National Kaohsiung University of Science and Technology, grant number NKUST-108D04.

Conflicts of Interest: The authors declare no conflict of interest. The authors alone are responsible for the content and writing of the manuscript.

\section{References}

1. Rees Clayton, E.M.; Specht, E.A.; Welch, D.R.; Berke, A.P. Addressing Global Protein Demand Through Diversification and Innovation: An Introduction to Plant-Based and Clean Meat; Melton, L., Shahidi, F., Varelis, P.B.T.-E.o.F.C., Eds.; Academic Press: Oxford, UK, 2019; pp. 209-217. [CrossRef]

2. Galaz, G.A. Chapter 20-An Overview on the History of Sports Nutrition Beverages; Bagchi, D., Nair, S., Sen, C.K.B.T.-N.a.E.S.P., Eds.; Academic Press: San Diego, CA, USA, 2013.

3. Kristinsson, H.G. 10-Aquatic food protein hydrolysates. In Woodhead Publishing Series in Food Science, Technology and Nutrition; Shahidi, F.B.T.-M.t.V.o.M.B.-P., Ed.; Woodhead Publishing: Sawston, UK, 2007; 229p.

4. Egerton, S.; Culloty, S.; Whooley, J.; Stanton, C.; Ross, R.P. Characterization of protein hydrolysates from blue whiting (Micromesistius poutassou) and their application in beverage fortification. Food Chem. 2018, 245, 698-706. [CrossRef] [PubMed]

5. Aoyama, J.; Watanabe, S.; Miyai, T.; Sasai, S.; Nishida, M.; Tsukamoto, K. The European eel, Anguilla anguilla (L.), in Japanese waters. Dana 2000, 12, 1-5.

6. Schlegel, T. Anguilla japonica. $F A O 1847,79,198-205$.

7. Heinsbroek, L.T.N. A review of eel culture in Japan and Europe. Aquac. Res. 1991, 22, 57-72. [CrossRef]

8. Minegishi, Y.; Aoyama, J.; Tsukamoto, K.J.M.E. Multiple population structure of the giant mottled eel, Anguilla marmorata. Mol. Ecol. 2008, 17, 3109-3122. [CrossRef] [PubMed]

9. Jamaluddin, J.; Agustinus, W. Comparative study of mineral content of sidat fish meat (anguilla marmorata quoy gaimard) on yellow eel phase from palu river and lake poso. J. Islamic Pharm. 2018, 3, 8-14. [CrossRef]

10. Everaert, I.; Stegen, S.; Vanheel, B.; Taes, Y.; Derave, W. Effect of beta-alanine and carnosine supplementation on muscle contractility in mice. Med. Sci. Sports Exerc. 2013. [CrossRef]

11. Khantaphant, S.; Benjakul, S. Comparative study on the proteases from fish pyloric caeca and the use for production of gelatin hydrolysate with antioxidative activity. Comp. Biochem. Physiol. Part B Biochem. Mol. Biol. 2008, 151, 410-419. [CrossRef]

12. Klompong, V.; Benjakul, S.; Yachai, M.; Visessanguan, W.; Shahidi, F.; Hayes, K.D. Amino Acid Composition and Antioxidative Peptides from Protein Hydrolysates of Yellow Stripe Trevally (Selaroides leptolepis). J. Food Sci. 2009, 74, C126-C133. [CrossRef]

13. Hartmann, R.; Meisel, H. Food-derived peptides with biological activity: From research to food applications. Curr. Opin. Biotechnol. 2007, 18, 163-169. [CrossRef]

14. Sila, A.; Sayari, N.; Balti, R.; Martinez-Alvarez, O.; Nedjar-Arroume, N.; Moncef, N.; Bougatef, A. Biochemical and antioxidant properties of peptidic fraction of carotenoproteins generated from shrimp by-products by enzymatic hydrolysis. Food Chem. 2014, 148, 445-452. [CrossRef] [PubMed] 
15. Mendis, E.; Rajapakse, N.; Kim, S.-K. Antioxidant properties of a radical-scavenging peptide purified from enzymatically prepared fish skin gelatin hydrolysate. J. Agric. Food Chem. 2005, 53, 581-587. [CrossRef] [PubMed]

16. Kristinsson, H.G.; Rasco, B.A. Fish protein hydrolysates: Production, biochemical, and functional properties. Crit. Rev. Food Sci. Nutr. 2000, 40, 43-81. [CrossRef] [PubMed]

17. Nikoo, M.; Benjakul, S.; Ahmadi Gavlighi, H.; Xu, X.; Regenstein, J.M. Hydrolysates from rainbow trout (Oncorhynchus mykiss) processing by-products: Properties when added to fish mince with different freeze-thaw cycles. Food Biosci. 2019. [CrossRef]

18. Gbogouri, G.A.; Linder, M.; Fanni, J.; Parmentier, M. Influence of Hydrolysis Degree on the Functional Properties of Salmon Byproducts Hydrolysates. J. Food Sci. 2004, 69, C615-C622. [CrossRef]

19. Nielsen, P.M.; Petersen, D.; Dambmann, C. Improved method for determining food protein degree of hydrolysis. J. Food Sci. 2001, 66, 642-646. [CrossRef]

20. Yang, X.; Wang, G.; Gong, X.; Huang, C.; Mao, Q.; Zeng, L.; Zheng, P.; Qin, Y.; Ye, F.; Lian, B.; et al. Effects of chronic stress on intestinal amino acid pathways. Physiol. Behav. 2019. [CrossRef]

21. Wang, T.; Zhou, Y.; Cao, S.; Lu, J.; Zhou, Y. Degradation of sulfanilamide by Fenton-like reaction and optimization using response surface methodology. Ecotoxicol. Env. Saf. 2019. [CrossRef]

22. Wang, C.-Y.; Chen, Y.-W.; Hou, C.-Y. Antioxidant and antibacterial activity of seven predominant terpenoids. Int. J. Food Prop. 2019. [CrossRef]

23. Kim, S.S.; Ahn, C.B.; Moon, S.W.; Je, J.Y. Purification and antioxidant activities of peptides from sea squirt (Halocynthia roretzi) protein hydrolysates using pepsin hydrolysis. Food Biosci. 2018. [CrossRef]

24. Zakaria, N.A.; Sarbon, N.M. Physicochemical properties and oxidative stability of fish emulsion sausage as influenced by snakehead (Channa striata) protein hydrolysate. LWT 2018. [CrossRef]

(C) 2020 by the authors. Licensee MDPI, Basel, Switzerland. This article is an open access article distributed under the terms and conditions of the Creative Commons Attribution (CC BY) license (http://creativecommons.org/licenses/by/4.0/). 